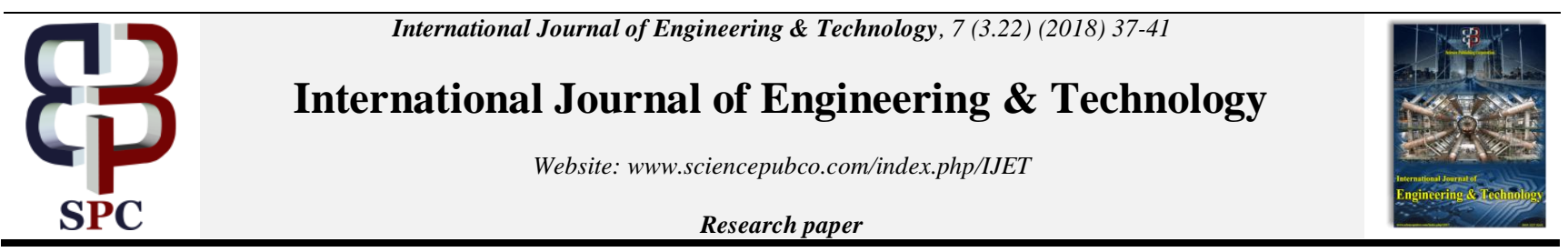

\title{
Neurofeedback for Anxiety Symptoms Among University Students
}

\author{
Jasmine Adela Mutang ${ }^{1}$, Chua Bee Seok $^{2}$, Shazia Iqbal Hashmi ${ }^{3}$ \\ ${ }^{1}$ Universiti Malaysia Sabah, Malaysia. \\ ${ }^{2}$ Universiti Malaysia Sabah, Malaysia. \\ ${ }^{3}$ Universiti Malaysia Sabah, Malaysia. \\ *Corresponding author E-mail: jasmine@ums.edu.my
}

\begin{abstract}
Anxiety is a common, universal human emotion, but excessive feelings of anxiety can negatively affect one's life satisfaction and quality of life. Psychotherapy and medication are the most common forms of intervention for anxiety disorders. In a recent development, researchers suggested that neurofeedback training (NFT) has the potential to reduce symptoms of anxiety, claiming to be less invasive while carrying fewer side effects compared to medication. Therefore, this preliminary study sought to assess whether neurofeedback training is a viable method to improve symptoms of anxiety in the nonclinical sample. Participants were randomly assigned to two groups (neurofeedback training group or a control group). Anxiety symptoms were assessed using the Depression, Anxiety and Stress Scale (DASS-21), the Beck Anxiety Inventory (BAI), and the State-Trait Anxiety Inventory (STAI). The findings showed an overall improvement in all of the psychological measurements in the neurofeedback group hence provide additional evidence to the field of neurotherapy that neurofeedback training is a viable option to improve anxiety symptoms among university students.
\end{abstract}

Keywords: Anxiety; Neurofeedback; Nonclinical Sample; Nonpharmacological Intervention; University Students

\section{Introduction}

In general, anxiety disorder may affect one's life satisfaction and quality of life (Grachev \& Apkarian, 2000; Rapaport, Clary, Fayyad, \& Endicott, 2005; Stein et al., 2005). Rapaport et. al (2005) also reported that the quality of life of those with anxiety disorders are equal, if not worse than those with other chronic medical mental disorders. Anxiety disorders result in personal stress and resistance to treatment, in addition to being associated with high health care costs because people who have generalized anxiety disorders may develop further conditions (Grachev \& Apkarian, 2000). The most common anxiety disorders are generalized anxiety disorder, panic disorder, social anxiety disorder, and post-traumatic stress disorder (PTSD) (Kroenke, Spitzer, Williams, Mohanan, \& Lowe, 2007).

Statistics and data around the globe reported there's an increase in prevalence of mental health issues, especially depression and anxiety (Mnookin, 2016; WHO, 2013). Studies also showed that anxiety disorders are one of the most common and has become a pandemic even among general populations (Michael, Zetche, \& Margaf, 2007). It was reported that the prevalence rates of anxiety disorders are between $16.6 \%$ and $28.8 \%$ worldwide (Walters, Rait, Griffin, Buszewicz, \& Nazareth, 2012). A large community survey done by the WHO in seventeen countries reported that the lifetime prevalence of anxiety disorders is $14.3 \%$ (Kessler, Chiu, Demier, \& Walters, 2005). The lifetime prevalence of GAD is $0.9 \%$ in Singapore, a country neighboring Malaysia (Chong et al., 2012).

The most common mental disorders diagnosed in Malaysia are depression, stress, and anxiety (Hassan, Hayati, \& Salmiah, 2015).
The 2011 Malaysia National Health and Morbidity Survey (NHMS)(Institute for Public Health (IPH) 2011, 2011) reported that the prevalence of Malaysian adults having generalized anxiety disorders $(1.7 \%)$ are consistent with global figures which is between $1.9 \%$ and $2.5 \%$. The NHMS (2011) survey found that those in in the age bracket of $16-24$ years had a higher prevalence $(2.1 \%)$ of generalized anxiety disorders and was just as high $(2.1 \%)$ among those with tertiary education. Therefore, based on the age group prevalence, university students may be among those most prone to mental illness.

Past studies revealed that the prevalence of mental health-related disorders with anxiety and stress are the most common ones among university students (Dachew, Bisetegn, \& Gebremariam, 2015; Lindsey, 2014; Sherina, Rampal, \& Kaneson, 2003). Campus life can be stressful because university students are entering a new phase of their adulthood life and need to adapt to a new environment, decision making, staying away from their families, financial management, managing daily life independently, and the need to cope with academic and social demands (Dyson \& Renk, 2006; Institute for Public Health (IPH) 2016, 2016; Shamsuddin et al., 2013). This predisposes university students to emotional disturbances such as stress, anxiety and depression. Although anxiety is common and adaptive especially in campus life, having excessive feelings of tension, prolonged worrying, and continuous stress may lead to serious mental health disorders such as anxiety and depressive symptoms (Chaló, Pereira, Batista, \& Sancho, 2017). 


\section{Literature Review}

A survey done on four public universities in Klang Valley to determine the prevalence of depression, anxiety, and stress among 506 university students reported that the prevalence of anxiety is much higher than either depression or stress (Shamsuddin et al., 2013). The study revealed that $29 \%$ had severe or extremely severe anxiety, and $18.6 \%$ had moderate anxiety. A similar study (Ali Sabri, Ghasak Ghazi, Syed Masroor, \& Maung Ko, 2014) was also conducted in one of the public universities in Selangor, revealing that the $51.5 \%$ had severe or extremely severe anxiety and $33 \%$ had moderate anxiety which is higher than in the study by Shamsuddin et al. (2013). Both studies used the Depression Anxiety, Stress Scale (DASS-21) to measure the severity of emotional disturbances. Another study done in Hong Kong was also done to determine the prevalence of depression, anxiety and stress among 7,915 first-year tertiary education students in Hong Kong using the DASS-42 version. The study found that $11.3 \%$ had severe anxiety, $7.6 \%$ had extremely severe anxiety, and $22.3 \%$ had moderate anxiety. Other studies done in the other regions also revealed a consistent trend in the prevalence of anxiety disorders among university students (Aktekin et al., 2001; Al-naggar \& Al-Naggar, 2012; Aldiabat, Matani, \& Le Navenec, 2014; Ozen, Ercan, Irgil, \& Sigirli, 2010; Regehr, Glancy, \& Pitts, 2013)

\subsection{Common Pharmacological and Nonpharmacologi- cal Therapy for Anxiety}

The most common mode of intervention for anxiety disorders are pharmacological and/or nonpharmacological strategies such as psychotherapies (Demos, 2005; Dilbaz \& Darcin, 2013). Most individuals diagnosed with anxiety disorders received pharmacological treatments such as antidepressants and anxiolytic drugs (Dilbaz \& Darcin, 2013). Some studies suggest that medication may not be effective, as between one-third to one-half of individuals on antidepressants do not achieve sustained remission from anxiety (Demos, 2005; Farach et al., 2012; Hammond, 2005b). About one third and one half of $30 \%$ and $50 \%$ individuals taking medication such as selective serotonin reuptake inhibitors (SSRis) experienced mild side effects such as nausea, diarrhea, headache and insomnia (Farach et al., 2012).

To date, the most common psychotherapy that and has been empirically established for treating anxiety disorders is cognitive behavioral therapy (CBT) (Dugas et al., 2010; Stein \& Craske, 2017). Cognitive behavioral therapy involves the leaning theory mechanism and focuses on three main components of anxiety symptoms, which are cognitive, affective/somatic, and behavior by applying certain techniques (Simpson, Neria, Lewis-Fernandez, \& Schneier, 2010). Individuals are trained to manage anxiety symptoms by applying arousal reduction techniques and coping skills to reduce levels of anxiety autonomic arousal (Dilbaz \& Darcin, 2013; Stein \& Craske, 2017). Psychotherapy in Malaysia focuses on changing behavior, mindset, perception and emotion. The proposed therapy in Malaysia for anxiety disorders are person-centered therapy, behavioral therapy, cognitive therapy, CBT, and neuropsychology recovery (Ministry of Health Malaysia, 2011).

\subsection{Neurofeedback Training (NFT) for Anxiety Symp- toms}

Research has indicated that anxiety disorders are associated with functional brain abnormalities (Hammond, 2005a; Heller, Etienne, $\&$ Miller, 1995; Wiedemann et al., 1999). In the past decades there is a growing interest in neurotherapy techniques or neurofeedback for various brain-related conditions including attention deficit hyperactivity disorder (ADHD), epilepsy, autism, and learning disabilities (Demos, 2005; Evans, 2007; Gunkelman \& Johnstone, 2005; Hammond, 2011a). Some studies have documented that the positive changes happening due to neurofeedback in these condi- tions were enduring after 1-year up to 10 year follow-ups (Bink, Bongers, Popma, Janssen, \& van Nieuwenhuizen, 2016; Coben \& Padolsky, 2016; Engelbregt et al., 2016). Hence, neurofeedback training may be an alternative or combined as a modality to psychotherapy (Hammond, 2011b). Demos (2005) emphasized that neurofeedback is a technological answer to psychotherapy, rehabilitation, and weak cerebral function. Neurotherapy is a form of modulation to change certain aspects of neuron function. The altering process of neuron function may happen through various experiences such as physical training, learning new tasks, or by neurofeedback training (Chapin \& Russell-Chapin, 2014). Neurofeedback assists individuals in controlling their brain waves consciously using feedback in the form or visual or/and audio means (Demos, 2005; Hammond, 2007, 2011b).

Neurofeedback training is a form of operant conditioning (Enriquez Geppert, Huster, \& Herrmann, 2017; Strehl, 2014). Typically, neurofeedback training involves the placement of one or more electrodes on certain areas of the scalp and two electrodes on the earlobes (Demos, 2005; Hammond, 2011b). An amplifier connected to the electrodes will then provide real time feedback about the individual's brain wave activity on the trainer's and participant's computer monitor. The electrical activity is conveyed to the computer and gives instantaneous feedback to both the trainer and individual. The real-time visual and audio feedbacks on the computer screen enable the individual on training to influence (increasing or decreasing) and gradually change the particular brain wave activity set by the trainer. This mechanism is based on operant conditioning (Hammond, 2011b). With continuous feedback and training, healthier brainwave patterns can be formed in most people.

Given the rates of anxiety and other related emotional disturbances among university students in Malaysia (Mohammed, Hayati, \& Salmiah, 2016; Shamsuddin et al., 2013; M. S. Sherina, Rampal, \& Kaneson, 2004; Yasin \& Dzulkifli, 2011) and the need to find modes of intervention that are safe and brief, the present study intends to examine the effectiveness of an 8 weeks (twice weekly, 18 minutes per session) neurofeedback training on reducing symptoms of anxiety on university student with high levels of anxiety. Therefore, the primary objective of this study is to investigate the application of neurofeedback training to improve symptoms of anxiety among university students.

\section{Materials and Methods}

\subsection{Participants}

A total of 20 participants who exhibited mild and severe level of anxiety symptoms based on the scores of the Depression, Anxiety and Stress Scale (DASS-21) (Lovibond \& Lovibond, 1995) Beck Anxiety Inventory (BAI) (Beck et al., 1996), and State-Trait Anxiety Inventory (STAI) volunteered to participate in the study. A total 10 participants were randomly assigned to NFT and another 10 participants (mean age $=22.6, S D=0.67 ;$ male $=2$, female $=$ 8 ) to the control group (mean age $=22.4, S D=.52$; male $=4$, female $=6$ ). All participants in both the NFT and control groups were free of psychotropic medication, previous history of psychiatric and neurological disorders, or substance abuse

\subsection{Instruments}

A within-subjects design was implemented in this preliminary study, which include a pre-assessment and post-assessment of their anxiety symptoms. The anxiety symptoms were assessed using the following instruments:

\subsubsection{Depression, Anxiety, and Stress Scale (DASS-21)}

The DASS-21 by Lovibond and Lovibond (1995) consists of 21 items measuring emotional states of depression (7 items), anxiety (7 items), and stress (7 items). Participants are asked to use 4 - 
point frequency scales to rate the extent to which they have experienced each symptom over the past week. Higher scores indicate more frequent symptomatology.

\subsubsection{Beck Anxiety Inventory (BAI)}

The BAI (Beck et al., 1996) is a self-report instrument consisting of 21 items measuring common symptoms of anxiety that have occurred over the past week. Each item is scored on a scale of 0 to $(0=$ no symptom presence to $4=$ I could barely stand (severe levels of the symptoms). The BAI is a brief measure of anxiety. It focuses on somatic symptoms of anxiety that was developed as a measure adept at discriminating between anxiety and depression (Beck, Epstein, Brown, \& Steer, 1988). Higher scores indicate greater anxiety symptomatology.

\subsubsection{State-Trait Anxiety Inventory (STAI)}

The STAI (Spielberger, 1983) comprises of separate self-report scales for measuring state anxiety and trait anxiety. Each item is scored on a 4-point rating scale ( 1 for "almost never" to 4 "almost always"), with higher scores indicating greater anxiety. Range of scores for each subtest (state and trait) is $20-80$.

\subsection{Neurofeedback Training}

EEGer Neurofeedback software by EEG Spectrum International Education and Research, Inc. and Thought Technology LTD manufactured amplifier was utilized in the neurofeedback training. The neurofeedback training occurred twice a week for eight weeks, each session lasting for 18 minutes. The training protocol employed based on the arousal checklist. The training site for all participants was at C4-A1. The training protocol intended to teach participants to decrease the power spectrum of slow $(2-5 \mathrm{~Hz}$ and $6-9 \mathrm{~Hz})$ and fast $(22-36 \mathrm{~Hz})$ activity while at the same time increasing mid-range $(12-15 \mathrm{~Hz})$ activity. Impedance was measured for both active and reference electrodes and maintained below 12 kOhms. Participants received game-like format training which utilized both visual and auditory feedback as reinforcement. The control group did not receive any intervention.

\section{Results}

In order to evaluate the influence of neurofeedback training, the NFT group and control group fill up the self-reported DASS-21, BAI and STAI measurements before the training and after the training. The scores of the tests were analyzed using nonparametric (Mann-Whitney U test and Wilcoxon Signed-Ranks test) analyses since the number of participants was small.

\subsection{Comparisons between NFT Group and Control Group of Pretest and Posttest Scores in DASS-21, BAI, and STAI}

The nonparametric Mann-Whitney U test was used to assess the statistical differences in the scores of DASS-21, BAI, and STAI between the NFT and control group. The analysis of pre-scores of the measurements suggests that both groups (NFT and control group) did not show any statistical difference in the DASS-21 (depression, anxiety and stress), BAI and STAI (state and trait anxiety) measurements before starting the NFT training. Table 1 displays the Mann-Whitney U Test between NFT and control groups.

Observation of the post-scores indicated there are significant differences between both groups in the DASS-21 depression and stress sub-scales. The Mann-Whitney $\mathrm{U}$ test indicated that the post-test scores of the NFT group (Mean Rank=7.11, $n=9$ ) were significantly lower that the control group in the DASS-21 depression scale $(U=19.00, z=-2.143, p=.032, r=0.492)$. Similarly in the
DASS-21 stress scale (Mean Rank=7.11, n=9) $U=19.00, z=-$ 2.142, $p=.032, r=0.491$ ) as depicted in Table 2.

Table 1: Results of the Mann-Whitney U Test to Compare the Groups' Pretest Scores in DASS-21, BAI, and STAI

\begin{tabular}{|c|c|c|c|c|c|c|c|}
\hline $\begin{array}{l}\text { Measure- } \\
\text { ment }\end{array}$ & Group & $\mathbf{n}$ & $\begin{array}{c}\text { Rank } \\
\text { Aver- } \\
\text { age }\end{array}$ & $\begin{array}{c}\text { Sum } \\
\text { of } \\
\text { Rank } \\
\text { S }\end{array}$ & $U$ & $z$ & $p$ \\
\hline \multirow{2}{*}{$\begin{array}{l}\text { DASS-21 } \\
\text { Depression } \\
\text { Pre-scores }\end{array}$} & $\begin{array}{l}\text { NFT } \\
\text { Group }\end{array}$ & 9 & 9.72 & 102.5 & \multirow[b]{2}{*}{$\begin{array}{c}42 . \\
5\end{array}$} & \multirow[b]{2}{*}{-.21} & \multirow[b]{2}{*}{$\begin{array}{l}.8 \\
4\end{array}$} \\
\hline & $\begin{array}{c}\text { Con- } \\
\text { trol }\end{array}$ & $\begin{array}{l}1 \\
0\end{array}$ & 10.25 & 87.5 & & & \\
\hline \multirow{2}{*}{$\begin{array}{c}\text { DASS-21 } \\
\text { Anxiety } \\
\text { Pre-scores }\end{array}$} & $\begin{array}{c}\text { NFT } \\
\text { Group }\end{array}$ & 9 & 11.89 & 83.00 & \multirow[b]{2}{*}{$\begin{array}{c}28 . \\
0\end{array}$} & \multirow{2}{*}{$\begin{array}{c}- \\
1.4 \\
0\end{array}$} & \multirow[b]{2}{*}{$\begin{array}{l}.1 \\
6\end{array}$} \\
\hline & $\begin{array}{c}\text { Con- } \\
\text { trol }\end{array}$ & $\begin{array}{l}1 \\
0\end{array}$ & 8.30 & $\begin{array}{c}107.0 \\
0\end{array}$ & & & \\
\hline \multirow{2}{*}{$\begin{array}{c}\text { DASS-21 } \\
\text { Stress } \\
\text { Pre-scores }\end{array}$} & $\begin{array}{c}\text { NFT } \\
\text { Group }\end{array}$ & 9 & 10.28 & 92.50 & \multirow[b]{2}{*}{$\begin{array}{c}42 . \\
5\end{array}$} & \multirow[b]{2}{*}{-.21} & \multirow[b]{2}{*}{$\begin{array}{l}.8 \\
4\end{array}$} \\
\hline & $\begin{array}{c}\text { Con- } \\
\text { trol }\end{array}$ & $\begin{array}{l}1 \\
0\end{array}$ & 9.75 & 97.50 & & & \\
\hline \multirow{2}{*}{$\begin{array}{c}\text { BAI } \\
\text { Pre-scores }\end{array}$} & $\begin{array}{c}\text { NFT } \\
\text { Group }\end{array}$ & 9 & 11.94 & 82.50 & \multirow{2}{*}{$\begin{array}{c}27 . \\
5\end{array}$} & \multirow{2}{*}{$\begin{array}{c}- \\
1.4 \\
4\end{array}$} & \multirow[b]{2}{*}{$\begin{array}{l}.1 \\
5\end{array}$} \\
\hline & $\begin{array}{c}\text { Con- } \\
\text { trol }\end{array}$ & $\begin{array}{l}1 \\
0\end{array}$ & 8.25 & $\begin{array}{c}107.5 \\
0\end{array}$ & & & \\
\hline \multirow{2}{*}{$\begin{array}{c}\text { STAI } \\
\text { State } \\
\text { Pre-scores }\end{array}$} & $\begin{array}{c}\text { NFT } \\
\text { Group }\end{array}$ & 9 & 9.67 & 87.00 & \multirow[b]{2}{*}{42} & \multirow[b]{2}{*}{-.25} & \multirow{2}{*}{$\begin{array}{l}.8 \\
1\end{array}$} \\
\hline & $\begin{array}{c}\text { Con- } \\
\text { trol }\end{array}$ & $\begin{array}{l}1 \\
0 \\
\end{array}$ & 10.30 & $\begin{array}{c}103.0 \\
0 \\
\end{array}$ & & & \\
\hline $\begin{array}{c}\text { Trait } \\
\text { Pre-scores }\end{array}$ & $\begin{array}{l}\text { NFT } \\
\text { Group }\end{array}$ & 9 & 11.28 & $\begin{array}{c}101.5 \\
0\end{array}$ & $\begin{array}{c}33 . \\
5\end{array}$ & -.95 & $\begin{array}{l}.3 \\
3\end{array}$ \\
\hline
\end{tabular}

Table 2: Results of the Mann Whitney U Test to Compare the Groups' Post Test Scores in the DASS-21, BAI, and STAI

\begin{tabular}{|c|c|c|c|c|c|c|c|}
\hline $\begin{array}{c}\text { Measure- } \\
\text { ment }\end{array}$ & Group & $\mathbf{n}$ & $\begin{array}{c}\text { Rank } \\
\text { Aver- } \\
\text { age }\end{array}$ & $\begin{array}{c}\text { Sum } \\
\text { of } \\
\text { Rank } \\
\text { s }\end{array}$ & $\boldsymbol{U}$ & $z$ & $p$ \\
\hline \multirow{2}{*}{$\begin{array}{l}\text { DASS-21 } \\
\text { Depression } \\
\text { Post-scores }\end{array}$} & $\begin{array}{l}\text { NFT } \\
\text { Group }\end{array}$ & 9 & 7.11 & 64.00 & \multirow[b]{2}{*}{$\begin{array}{c}19.0 \\
0\end{array}$} & \multirow{2}{*}{$\begin{array}{c}- \\
2.14 \\
3\end{array}$} & \multirow{2}{*}{$\begin{array}{c}.032 \\
*\end{array}$} \\
\hline & $\begin{array}{c}\text { Con- } \\
\text { trol }\end{array}$ & $\begin{array}{l}1 \\
0\end{array}$ & 12.60 & $\begin{array}{c}126.0 \\
0\end{array}$ & & & \\
\hline \multirow{2}{*}{$\begin{array}{c}\text { DASS-21 } \\
\text { Anxiety Post- } \\
\text { scores }\end{array}$} & $\begin{array}{l}\text { NFT } \\
\text { Group }\end{array}$ & 9 & 7.67 & 69.00 & \multirow[b]{2}{*}{$\begin{array}{c}24.0 \\
0\end{array}$} & \multirow{2}{*}{$\begin{array}{c}- \\
1.73 \\
3\end{array}$} & \multirow[b]{2}{*}{0.83} \\
\hline & $\begin{array}{c}\text { Con- } \\
\text { trol }\end{array}$ & $\begin{array}{l}1 \\
0\end{array}$ & 12.10 & $\begin{array}{c}121.0 \\
0\end{array}$ & & & \\
\hline \multirow{2}{*}{$\begin{array}{l}\text { DASS-21 } \\
\text { Stress Post- } \\
\text { scores }\end{array}$} & $\begin{array}{l}\text { NFT } \\
\text { Group }\end{array}$ & 9 & 7.11 & 64.00 & \multirow[b]{2}{*}{$\begin{array}{c}19.0 \\
0\end{array}$} & \multirow{2}{*}{$\begin{array}{c}- \\
2.14 \\
2\end{array}$} & \multirow{2}{*}{$\begin{array}{c}.032 \\
*\end{array}$} \\
\hline & $\begin{array}{c}\text { Con- } \\
\text { trol }\end{array}$ & $\begin{array}{l}1 \\
0\end{array}$ & 12.60 & $\begin{array}{c}126.0 \\
0\end{array}$ & & & \\
\hline \multirow{2}{*}{$\begin{array}{l}\text { BAI Post- } \\
\text { scores }\end{array}$} & $\begin{array}{l}\text { NFT } \\
\text { Group }\end{array}$ & 9 & 8.72 & 78.50 & \multirow[b]{2}{*}{$\begin{array}{c}33.5 \\
0\end{array}$} & \multirow[b]{2}{*}{-.941} & \multirow[b]{2}{*}{.347} \\
\hline & $\begin{array}{c}\text { Con- } \\
\text { trol }\end{array}$ & $\begin{array}{l}1 \\
0\end{array}$ & 11.15 & $\begin{array}{c}111.5 \\
0\end{array}$ & & & \\
\hline \multirow{2}{*}{$\begin{array}{l}\text { STAI } \\
\text { State Post- } \\
\text { scores }\end{array}$} & $\begin{array}{c}\text { NFT } \\
\text { Group }\end{array}$ & 9 & 7.50 & 67.50 & \multirow{2}{*}{$\begin{array}{c}22.5 \\
0\end{array}$} & \multirow[b]{2}{*}{-1.85} & \multirow[b]{2}{*}{.064} \\
\hline & $\begin{array}{c}\text { Con- } \\
\text { trol }\end{array}$ & $\begin{array}{l}1 \\
0\end{array}$ & 12.25 & $\begin{array}{c}122.5 \\
0 \\
\end{array}$ & & & \\
\hline $\begin{array}{c}\text { Trait Post- } \\
\text { scores }\end{array}$ & $\begin{array}{l}\text { NFT } \\
\text { Group }\end{array}$ & 9 & 8.50 & 76.50 & $\begin{array}{c}31.5 \\
0\end{array}$ & $\begin{array}{c}- \\
1.10 \\
7\end{array}$ & .268 \\
\hline
\end{tabular}

\subsection{Comparisons of Pretest and Posttest Scores in DASS-21, BAI, and STAI within NFT Group and Con- trol}

In order to assess the statistical differences between the pre-scores and post-scores of DASS-21, BAI and STAI measurements within the NFT group, the nonparametric Wilcoxon signed-rank test was conducted. As displayed in Table 3, there are significant differences between the pre-test and post-test scores of all psychological measurements within the NFT group. The analysis indicated that the post-test scores in all measurements decreased among the NFT participants after the neurofeedback training. This suggested that neurofeedback staining significantly improve the anxiety scores 
based on the ratings of DASS-21, BAI and STAI the of the NFT group.

As shown in Table 4, there are no significant differences between the pre-test and post-test scores in all the measurement except for the DASS-2 1 stress scale $(\mathrm{z}=-2.536, \mathrm{p}=.011, \mathrm{r}=.896)$ and state anxiety scale of the STAI instrument $(\mathrm{z}=-2.295, \mathrm{p}=.022, \mathrm{r}=.726)$. Given the sum of ranks for the difference scores, the observed difference are not in favor of positives ranks across all measurements except for the DASS-21 stress scale (negative sum ranks= 36 , positive sum ranks $=0$ ) and state anxiety scale of the STAI instrument (negative sum ranks $=6.25$, positive sum ranks $=.2 .5$ ).

Table 3: Results of the Wilcoxon Signed-Ranks Test on the PretestPosttest Scores in the DASS-21, BAI, and STAI in the NFT Group

\begin{tabular}{|c|c|c|c|c|c|c|c|}
\hline $\begin{array}{l}\text { Measure- } \\
\text { men ts }\end{array}$ & & $N$ & $\begin{array}{c}\text { Mea } \\
\mathbf{n} \\
\text { Ran } \\
\mathbf{k} \\
\end{array}$ & 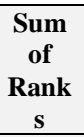 & $z$ & $p$ & $r$ \\
\hline \multirow[t]{3}{*}{$\begin{array}{c}\text { DASS-21 } \\
\text { Depression } \\
\text { Post-scores }\end{array}$} & $\begin{array}{l}\text { Nega- } \\
\text { tive } \\
\text { rank }\end{array}$ & 8 & 4.5 & 36 & \multirow{3}{*}{$\begin{array}{c}- \\
2.52 \\
7\end{array}$} & \multirow{3}{*}{$\begin{array}{c}.012 \\
*\end{array}$} & \multirow{3}{*}{$\begin{array}{c}0.89 \\
3\end{array}$} \\
\hline & $\begin{array}{c}\text { Positive } \\
\text { Rank }\end{array}$ & 0 & .00 & .00 & & & \\
\hline & Ties & 1 & & & & & \\
\hline \multirow[t]{3}{*}{$\begin{array}{c}\text { DASS-21 } \\
\text { Anxiety } \\
\text { Post-scores }\end{array}$} & $\begin{array}{l}\text { Nega- } \\
\text { tive } \\
\text { rank }\end{array}$ & 9 & 5 & 45 & \multirow{3}{*}{$\begin{array}{c}2.67 \\
0\end{array}$} & \multirow{3}{*}{$\begin{array}{c}.008 \\
*\end{array}$} & \multirow{3}{*}{0.89} \\
\hline & $\begin{array}{c}\text { Positive } \\
\text { Rank }\end{array}$ & 0 & .00 & .00 & & & \\
\hline & Ties & 0 & & & & & \\
\hline \multirow[t]{3}{*}{$\begin{array}{c}\text { DASS-21 } \\
\text { Stress } \\
\text { Post-scores }\end{array}$} & $\begin{array}{l}\text { Nega- } \\
\text { tive } \\
\text { rank }\end{array}$ & 9 & 5 & 45 & \multirow{3}{*}{$\begin{array}{c}- \\
2.68 \\
0\end{array}$} & \multirow{3}{*}{$\begin{array}{c}.007 \\
*\end{array}$} & \multirow{3}{*}{$\begin{array}{c}0.89 \\
3\end{array}$} \\
\hline & $\begin{array}{c}\text { Positive } \\
\text { Rank }\end{array}$ & 0 & .00 & .00 & & & \\
\hline & Ties & 0 & & & & & \\
\hline \multirow[t]{3}{*}{$\begin{array}{c}\text { BAI } \\
\text { Post-scores }\end{array}$} & $\begin{array}{c}\text { Nega- } \\
\text { tive } \\
\text { rank }\end{array}$ & 9 & 5 & 45 & \multirow{3}{*}{$\begin{array}{c}- \\
2.54 \\
7\end{array}$} & \multirow{3}{*}{$\begin{array}{c}.011 \\
*\end{array}$} & \multirow{3}{*}{$\begin{array}{c}0.84 \\
9\end{array}$} \\
\hline & $\begin{array}{c}\text { Positive } \\
\text { Rank }\end{array}$ & 0 & .00 & .00 & & & \\
\hline & Ties & 0 & & & & & \\
\hline \multirow[t]{3}{*}{$\begin{array}{c}\text { STAI } \\
\text { State Post- } \\
\text { scores }\end{array}$} & $\begin{array}{l}\text { Nega- } \\
\text { tive } \\
\text { rank }\end{array}$ & 8 & 5.5 & 44 & \multirow{3}{*}{$\begin{array}{c}- \\
2.31 \\
2\end{array}$} & \multirow{3}{*}{$\begin{array}{c}.021 \\
*\end{array}$} & \multirow{3}{*}{$\begin{array}{c}0.81 \\
7\end{array}$} \\
\hline & $\begin{array}{c}\text { Positive } \\
\text { Rank }\end{array}$ & 1 & 1.00 & 1.00 & & & \\
\hline & Ties & 0 & & & & & \\
\hline \multirow[t]{3}{*}{$\begin{array}{l}\text { Trait Post- } \\
\text { scores }\end{array}$} & $\begin{array}{l}\text { Nega- } \\
\text { tive } \\
\text { rank }\end{array}$ & 8 & 5.25 & 42 & \multirow{3}{*}{$\begin{array}{c}- \\
2.68 \\
0\end{array}$} & \multirow{3}{*}{$\begin{array}{c}.007 \\
*\end{array}$} & \multirow{3}{*}{$\begin{array}{c}0.94 \\
7\end{array}$} \\
\hline & $\begin{array}{c}\text { Positive } \\
\text { Rank }\end{array}$ & 1 & .00 & .00 & & & \\
\hline & Ties & 0 & & & & & \\
\hline
\end{tabular}

Table 4: Results of the Wilcoxon Signed-Ranks Test on the PretestPosttest Scores in the DASS-21, BAI, and STAI in the Control Group

\begin{tabular}{|c|c|c|c|c|c|c|c|}
\hline $\begin{array}{l}\text { Measure- } \\
\text { ments }\end{array}$ & & $N$ & $\begin{array}{l}\text { Mean } \\
\text { Rank }\end{array}$ & $\begin{array}{c}\text { Sum } \\
\text { of } \\
\text { Ranks }\end{array}$ & $z$ & $p$ & $r$ \\
\hline \multirow{3}{*}{$\begin{array}{c}\text { DASS-21 } \\
\text { Depression } \\
\text { Post-scores }\end{array}$} & $\begin{array}{l}\text { Negative } \\
\text { rank }\end{array}$ & 7 & 5.43 & 38 & \multirow{3}{*}{$\begin{array}{c}- \\
1.849\end{array}$} & \multirow{3}{*}{.064} & \multirow{3}{*}{.616} \\
\hline & $\begin{array}{c}\text { Positive } \\
\text { Rank }\end{array}$ & 2 & 3.4 & 7 & & & \\
\hline & Ties & 1 & & & & & \\
\hline \multirow{3}{*}{$\begin{array}{c}\text { DASS-21 } \\
\text { Anxiety Post- } \\
\text { scores }\end{array}$} & $\begin{array}{l}\text { Negative } \\
\text { rank }\end{array}$ & 8 & 5.69 & 45.5 & \multirow{3}{*}{$\overline{-}$} & \multirow{3}{*}{.065} & \multirow{3}{*}{.584} \\
\hline & $\begin{array}{c}\text { Positive } \\
\text { Rank }\end{array}$ & 2 & 4.75 & 9.5 & & & \\
\hline & Ties & 0 & & & & & \\
\hline \multirow{3}{*}{$\begin{array}{c}\text { DASS-21 } \\
\text { Stress Post- } \\
\text { scores }\end{array}$} & $\begin{array}{l}\text { Negative } \\
\text { rank }\end{array}$ & 8 & 4.5 & 36 & \multirow{3}{*}{2.536} & \multirow{3}{*}{$.011^{*}$} & \multirow{3}{*}{.896} \\
\hline & $\begin{array}{l}\text { Positive } \\
\text { Rank }\end{array}$ & 0 & .00 & .00 & & & \\
\hline & Ties & 2 & & & & & \\
\hline $\begin{array}{l}\text { BAI Post- } \\
\text { scores }\end{array}$ & $\begin{array}{l}\text { Negative } \\
\text { rank }\end{array}$ & 7 & 5.64 & 39.5 & $1 . \overline{-} 227$ & .220 & .388 \\
\hline
\end{tabular}

\begin{tabular}{|c|c|c|c|c|c|c|c|}
\hline & $\begin{array}{l}\text { Positive } \\
\text { Rank }\end{array}$ & 3 & 5.17 & 15.5 & & & \\
\hline & Ties & 0 & & & & & \\
\hline \multirow{3}{*}{$\begin{array}{c}\text { STAI } \\
\text { State Post- } \\
\text { scores }\end{array}$} & & & & & \multirow{3}{*}{$2 . \overline{-}$} & \multirow{3}{*}{$.022^{*}$} & \multirow{3}{*}{.726} \\
\hline & $\begin{array}{l}\text { Negative } \\
\text { rank }\end{array}$ & 8 & 6.25 & 50 & & & \\
\hline & $\begin{array}{c}\text { Positive } \\
\text { Rank }\end{array}$ & 2 & 2.5 & 5 & & & \\
\hline \multirow{3}{*}{$\begin{array}{l}\text { Trait Post- } \\
\text { scores }\end{array}$} & Ties & 0 & & & \multirow{3}{*}{$1 . \overline{-}$} & \multirow{3}{*}{.155} & \multirow{3}{*}{.474 } \\
\hline & $\begin{array}{l}\text { Negative } \\
\text { rank }\end{array}$ & 7 & 4.93 & 34.5 & & & \\
\hline & $\begin{array}{c}\text { Positive } \\
\text { Rank }\end{array}$ & 2 & 5.25 & 10.5 & & & \\
\hline
\end{tabular}

\section{Conclusion}

Given the preliminary nature of this study, there are several considerations that need to be taken into account for the next phase of this study. The statistical analysis results only shows significant difference in the post-test scores of the DASS-21 depression and stress subscales between NFT and control group. However, the values of mean rank and sum of ranks across all measurements for the NFT group are lower than the control group. It is also worth to note that the total scores and mean scores of all measurements showed noticeable improvements (post assessment) in all scales for the NFB group as compared to the control group. The researchers believe that more NFT sessions may statistically improve the results. The last NFT session was completed a week before the semester break, hence it was not possible to continue with more than fifteen sessions. The next study will consider an average seven to twelve hours of NFT training (17-19 sessions) as suggested by Hammond (2005b) and increasing the time This study only employed eighteen minutes per session and increasing the time to 20-30 minutes per session may yield significant improvement (Dreis et al., 2015; Yucha \& Montgomery, 2008). Since this study involved a small sample, a bigger sample will be needed for the next phase of this study by taking into account effect size to ensure a more reliable evidence of the effects of NFT on anxiety symptoms among non-clinical samples. Finally, the next phase of the study might consider employing an active control group to truly determine the effect of NFB training. The growing numbers of mental health problems among university students, especially stress, anxiety, and depression makes them a population at risk (Meier and Welch 2015). On the basis of the results obtained in the preliminary analyses, neurofeedback training is a potential intervention to significantly improve anxiety symptoms among students sample and deserves further investigation for its potential to improve the wellbeing and quality of life of this particular group.

\section{Acknowledgement}

This research is supported by the Postgraduate Research Grant (UMSGreat; No: GUG0207-1/2018), Universiti Malaysia Sabah.

\section{References}

[1] Aktekin M, Karaman T, Senol YY, Erdem S, Erengin H \& Akaydin M, "Anxiety, Depression and Stressful Life Events among Medical Students: A Prospective Study in Antalya, Turkey", Medical Education, Vol.35,(2001),pp.12-17.

[2] Aldiabat KM, Matani NA \& Le Navenec CL, "Mental Health among Undergraduate University Students: A Background Paper for Administrators, Educators and Healthcare Providers", Universal Journal of Public Health,Vol.2,No.8,(2014),pp.209-214.

[3] Ali Sabri R, Ghasak Ghazi F, Syed Masroor A \& Maung Ko, HMI "Source of Stressors and Emotional Disturbances among Undergraduate Science Students in Malaysia", International Journal of Medical Research \& Health Sciences, Vol.3,No.2, (2014),pp.401-410.

[4] Al-naggar RA \& Al-Naggar DH, "Prevalence and Associated Factors of Emotional Disorder among Malaysian University Students", International Journal of Collaborative Research on Internal Medicine 
\& Public Health,Vol.14,No.7, (2012),pp.1401-1410.

[5] Beck AT, Epstein N, Brown G, \& Steer RA, "An Inventory For Measuring Clinical Anxiety: Psychometric Properties", Journal of Consulting and Clinical Psychology,Vol.56,No.6,(1988), pp.893-897.

[6] Bink M, Bongers IL, Popma A, Janssen TWP \& van Nieuwenhuizen C, "1-Year Follow-Up of Neurofeedback Treatment in Adolescents With Attention-Deficit Hyperactivity Disorder: Randomised Controlled Trial", British Journal of Psychiatry Open, Vol.2,No.2,(2016),pp.107-115.

[7] Chaló P, Pereira A, Batista P \& Sancho L, "Brief Biofeedback Intervention on Anxious Freshman University Students", Applied Psychophysiology Biofeedback", Vol.42,No.3,(2017), pp.163-168.

[8] Chapin TJ \& Russell-Chapin LA, Neurotherapy and Neurofeedback: Brain-Based Treatment for Psychological and Behavioral Problems, Routledge, (2014),pp. 1-220.

[9] Chong SA, Abdin E, Vaingankar JA, Heng D, Sherbourne CD, Yap M, ... Subramaniam M, "A Population-Based Survey of Mental Disorders in Singapore", Annals of the Academy of Medicine,Vol.41,No.2, (2012),pp.49-66.

[10] Coben R \& Padolsky I, "Assessment-Guided Neurofeedback for Autistic Spectrum Disorder", Journal of Neurotherapy, Vol.11,No.1, (2016),pp.5-23.

[11] Dachew BA, Bisetegn TA \& Gebremariam RB, "Prevalence of Mental Distress and Associated Factors among Undergraduate Students of University of Gondar, Northwest Ethiopia: A Cross-Sectional Institutional Based Study", PLOS ONE, Vol.10,No.3,(2015),pp.1-10.

[12] Demos JN, Getting Started with Neurofeedback,W.W Norton \& Company, (2005), pp. 1-272.

[13] Dilbaz N \& Darcin AE, Treatment of Generalized Anxiety Disorders : Unmet Needs. In Federico Durbano (Ed.), New Insights into Anxiety Disorders, (2013), IntechOpen, pp. 327-342, available online https://www.intechopen.com/books/new-insights-into-anxietydisorders/treatment-of-generalized-anxiety-disorders-unmet-needs, 10.03.2018.

[14] Dreis SM, Gouger AM, Perez EG, Russo GM, Fitzsimmons MA \& Jones MS, "Using Neurofeedback to Lower Anxiety Symptoms Using Individualized qEEG Protocols: A Pilot Study", NeuroRegulation,Vol.2,No.3, (2015),pp.137-148.

[15] Dugas MJ, Brillon P, Savard P, Turcotte J, Gaude, A, Ladouceur R, .. Gervais NJ, "A Randomized Clinical Trial of Cognitive-Behavioral Therapy and Applied Relaxation for Adults With Generalized Anxiety Disorder”, Behavior Therapy, Vol.41,No.1, (2010),pp.46-58.

[16] Dyson R \& Renk K, "Freshmen Adaptation to University Life: Depressive Symptoms, Stress, and Coping", Journal of Clinical Psychology,Vol.62,No.10, (2006),pp.1231-1244.

[17] Engelbregt HJ, Keeser, D, van Eijk, L, Suiker, EM, Eichhorn, D, Karch, S, ... Pogarell, O, "Short And Long-Term Effects Of Sham-Controlled Prefrontal EEG-Neurofeedback Training In Healthy Subjects", Clinical Neurophysiology, Vol.127,No.4, (2016),pp.1931-1937.

[18] Enriquez Geppert, S, Huster, RJ \& Herrmann, C, "EEG-Neurofeedback As A Tool to Modulate Cognition and Behavior: A Review Tutorial", Frontiers in Human Neuroscience, Vol.11,No.51, (2017),pp.1-19.

[19] Evans JR, Handbook of Neurofeedback: Dynamics and Clinical Applications, The Haworth Medical Press, (2007),pp.1-378.

[20] Farach FJ, Pruitt LD, Jun JJ, Jerud AB, Zoellner LA, \& Roy-Byrne PP, "Pharmacological Treatment of Anxiety Disorders: Current Treatments and Future Directions", Journal of Anxiety Disorders, Vol.26,No.8,(2012),pp.833-843.

[21] Grachev ID \& Apkarian AV, "Anxiety in Healthy Humans is Associated with Orbital Frontal Chemistry", Molecular Psychiatry, Vol.5,No.5,(2000),pp.482-488.

[22] Gunkelman JD \& Johnstone J,"Neurofeedback and the Brain”, Journal of Adult Development, Vol.12,No.2/3, (2005), pp.93-98.

[23] Hammond DC, "Neurofeedback Treatment of Depression and Anxiety", Journal of Adult Development, Vol.12,No.2/3, (2005a),pp.131-137.

[24] Hammond DC, "Neurofeedback with Anxiety and Affective Disorders", Child and Adolescent Psychiatric Clinics of North America, Vol.14,(2005b), pp.105-123.

[25] Hammond DC, "What is Neurofeedback: An Update", Journal of Neurotherapy, Vol.15,No.4,(2011),pp.305-336.

[26] Hassan M, Hayati, K \& Salmiah M,"Are Fresh Undergraduate Students in A Public University Free Of Psychological Problems: A Proposed Study of Depression, Anxiety, Stress and Their Coping Mechanisms", International Journal of Public Health and Clinical Sciences, Vol.2,No.1,(2015),pp. 174-190.

[27] Heller W, Etienne MA \& Miller GA, "Patterns of Perceptual Asymmetry in Depression and Anxiety: Implications for Neuropsychological Models of Emotion and Psychopathology", Journal of Abnormal Psychology, Vol.104,No.2,(1995),pp.327-33.

[28] Institute for Public Health (IPH) 2016, National Health and Morbidity Survey 2016 (NHMS 2016): Maternal and Child Health. Vol. I: Methodology and General Findings,Institute for Public Health, (2016),pp.1110.

[29] Institute for Public Health (IPH) 2016, National Health and Morbidity Survey 2016 (NHMS 2016): Maternal and Child Health. Vol. I:
Methodology and General Findings, Institute for Public Health, (2016), pp. 1-176.

[30] Kessler RC, Chiu WT, Demier O \& Walters EE,"Prevalence, Severity, and Comorbidity of Twelve-month DSM-IV Disorders in the National Comorbidity Survey Replication (NCS- R)", Archives of General Psychiatry,Vol.62,No.6, (2005),pp.617-627.

[31] Kroenke K, Spitzer RL, Williams JBW, Mohanan PO \& Lowe B, “Anxiety Disorders in Primary Care: Prevalence, Impairment, Comorbidity, and Detection", Annals Internatioal Medical Journal, Vol.146, No.5, (2005), pp. 317-325.

[32] Lindsey C, "Trait Anxiety in College Students: The Role of the Approval Seeking Schema and Separation Individuation", College Student Journal, Vol.48, No.3, (2014), pp.407-418.

[33] Michael T, Zetche U \& Margaf J, "Epidemiology of Anxiety Disorders", Psychiatry, Vol.6, No.4, (2007), pp.136-142.

[34] Ministry of Health Malaysia, Psychiatric and Mental Health Services Operational Policy, Ministry of Health Malaysia, (2011), pp. 1-121.

[35] Mnookin S, Out of the Shadows: Making Mental Health a Global Development Priority, World Bank Group, (2016) Availableonlinehttp://documents.worldbank.org/curated/en/270131468187

759113/Out-of-the-shadows-making-mental-health-a-global-developmentpriority, last visit: 12.03 .2018

[36] Mohammed H, Hayati KS \& Salmiah MS, “Coping with Depression, Anxiety, and Stress: A Cross-Sectional Study among Malaysian Students in A Public University",Journal of Dental and Medical Sciences, Vol.15,No.11, (2016),pp.83-95.

[37] Ozen NS, Ercan I, Irgil E \& Sigirli D, "Anxiety Prevalence and Affecting Factors Among University Students", Asia Pacific Journal of Public Health, Vol.22, No.1, (2010), pp.127-133.

[38] Rapaport MH, Clary C, Fayyad R \& Endicott J, "Quality-of-Life in Depressive and Anxiety Disorders", American Journal of Psychiatry, Vol.162, No.6, (2005), pp.1171-1178.

[39] Regehr C, Glancy D \& Pitts A, "Interventions to Reduce Stress in University Students: A Review and Meta-Analysis", Journal of Affective Disorders, Vol.148, No.1, (2013), pp.1-11.

[40] Sahoo S \& Khess CRJ,"Prevalence of Depression, Anxiety, and Stress Among Young Male Adults in India",The Journal of Nervous and Mental Disease,Vol.198,No.12,(2010),pp.901-904.

[41] Shamsuddin K, Fadzil F, Ismail WSW, Shah SA, Omar K, Muhammad NA, ... Mahadevan R, "Correlates of Depression, Anxiety and Stress among Malaysian University Students", Asian Journal of Psychiatry, Vol.6,No.4, (2013), pp.318-323.

[42] Sherina M, Rampal L \& Kaneson N, "Prevalence of Emotional Disorders among Medical Students in A Malaysian University”. Asia Pacific Family Medicine, Vol.2, (2003), pp.213-217.

[43] Simpson, HB, Neria, Y, Lewis-Fernandez, R \& Schneier, F, "Cognitive-behavioral treatment of anxiety disorders: model and current issues", Anxiety Disorders: Theory, Research, and Clinical Perspectives, Cambridge University Press, (2010), pp. 204-215.

[44] Stein MB \& Craske MG, "Treating Anxiety in 2017: Optimizing Care to Improve Outcomes", JAMA, Vol.318, No.3, (2017), pp.235-236.

[45] Stein MB, Roy-Byrne PP, Craske MG, Bystritsky A, Sullivan G., Pyne JM., ... Sherbourne CD, "Functional Impact and Health Utility of Anxiety Disorders in Primary Care Outpatients", Medical Care, Vol.43, No.12, (2005), pp.1164-1170.

[46] Strehl U, "What Learning Theories Can Teach Us in Designing Neurofeedback Treatments", Frontiers in Human Neuroscience, Vol.8, (2014), pp.894.

[47] Walters K, Rait G, Griffin M., Buszewicz M, \& Nazareth I, "Recent Trends in the Incidence of Anxiety Diagnoses and Symptoms in Primary Care",PLOS ONE,Vol.7,No.8, (2012),pp.1-9

[48] WHO, Mental Health Action Plan 2013-2020, WHO Document Production Services, (2013), pp.1-48.

[49] Wiedemann G, Pauli P, Dengler W, Lutzenberger W, Birbaumer N, \& Buchkremer G, "Frontal Brain Asymmetry as A Biological Substrate of Emotions in Patients with Panic Disorders", Archives of General Psychiatry,Vol.56,No.1, (1999), pp.78-84.

[50] Yasin AS \& Dzulkifli MA, "Differences in Depression, Anxiety and Stress between Low-And High-Achieving Students", Journal of Sustainability Science and Management, Vol.6, No.1, (2011), pp.169-178.

[51] Yucha C \& Montgomery D, Evidence-Based Pactice in Biofeedback and Neurofeedback, (2008). Association for Applied Psychophysiology. 